\title{
The Comparison of Leukocyte Numbers, Hematocrit Values and Complement Levels between the Two Lines Selected for High and Low Competences in Graft-versus-host Reaction
}

\author{
Suguru Mashima, Jin-ichi Okumura ${ }^{1}$, Ikuo Okada ${ }^{2}$ \\ and Kouzaburoh Yамамото ${ }^{1}$ \\ Graduate school of Science and Technology, Niigata University \\ ${ }^{1}$ Faculty of Agriculture, Niigata University, Niigata-shi, 950-21 \\ ${ }^{2}$ Faculty of Applied Biological Science, Hiroshima University, \\ Higashi-Hiroshima-shi, 724
}

\begin{abstract}
The two lines of chickens which were selected for high and low competences in graft-versus-host reaction (GVHR) were compared for leukocyte numbers, hematocrit values and hemolytic complement levels at 3,6 and 9 weeks of age. Both lines have the same genotype at the major histocompatibility B locus. Low responder line had more leukocytes and showed higher hematocrit values as compared with High responder lines. Lymphoproliferative ability of the two lines on the occasion of antigenic stimulation was discussed in relation to resistance to Marek's disease and leukocyte number.

On the other hand, hemolytic complement level was higher in High responder line than in Low responder line. These lines would be useful for studying the complement system of chickens.
\end{abstract}

(Jpn. Poult. Sci., 28: 256-260, 1991)

Key words : hemolytic complement level, leukocyte number, hematocrit value.

\section{Introduction}

Two White Leghorn lines, HA and LA, were developed by selections for high and low competences for splenomegaly in graft-versus-host-reaction (GVHR) ${ }^{1}$. Both lines have the same genotype at the major histocompatibility B locus (MHC) of chickens. The lines showed differences in some immunocompetences ${ }^{1-5)}$. HA showed higher immune responses to the dinitrophenyl group conjugated chicken gamma globulin (DNP-CGG) as compared with $\mathrm{LA}^{2)}$. Contrary to this, mortality and incidence in Marek's disease (MD) were lower in the LA line than in HA line ${ }^{4}$.

The objective of this study is to obtain further hematological and immunological informations about these lines. The peripheral leukocyte numbers, hematocrit values and complement levels were examined in both lines.

\section{Materials and Methods}

Two White Leghorn lines, HA and LA, were used for the experiment. The HA and LA lines had been established by selections for high and low competences in GVHR. 
Both lines have the same B genotype. Sixteen birds of the HA line and eleven individuals of the LA line were employed for the experiment. Blood was collected from a wing vein with a heparinized syringe at 3,6 and 9 weeks of age.

The numbers of peripheral leukocyte was determined as previously described ${ }^{6}$. Briefly, blood diluted with Pilot's solution was mounted in 3 hemocytometers and total leukocyte numbers were determined by counting the leukocytes under a light microscope at $\times 640$. Blood smears stained with the Wright-Giemsa method were also observed at $\times 1000$ and leukocytes were classified into lymphocytes, granulocytes and monocytes. The percentages of those cells were determined by counting 900 leukocytes in 3 fields. Counting was carried out three times on each sample. Differential counts of each leukocyte were calculated from total leukocyte number and the percentage of each cell type.

Hemolytic complement levels were estimated by the method of $\mathrm{CHANH}^{77}$. Tris buffer (10 mM tris, pH 7.4) was routinely used in the experiment. A rabbit hemolysin (Denkaseiken) diluted 1:300 was used to presensitize standardized 1\% sheep erythrocytes (EA) at $37^{\circ} \mathrm{C}$ for $30 \mathrm{~min}$. The sensitized EA was washed three times with the buffer. The initial dilution of plasma was $1: 60$ for 3 week-old birds and $1: 80$ for 6- and 9-week-old birds. The final dilutions were $1: 120$ for 3 week-old birds and $1: 160$ for 6 - and 9-week-old birds. Five dilutions were made for each plasma between the initial and the final dilution. One $\mathrm{m} l$ of diluted plasma and $0.2 \mathrm{~m} l$ of EA were reacted in a tube in a water bath at $37^{\circ} \mathrm{C}$ for $30 \mathrm{~min}$. Then, the reaction was terminated by adding $2 \mathrm{~m} l$ of icecold isotonic citrate-saline solution ( $15 \mathrm{mM}$ sodium citrate, $0.12 \mathrm{M}$ sodium chloride). Tubes were centrifuged at $2000 \mathrm{rpm}$ for $15 \mathrm{~min}$ at $4^{\circ} \mathrm{C}$, followed by decanting supernatant into another tube. Hemoglobin content was determined by spectrophotometer at $412 \mathrm{~nm}$ of wave length. The $\mathrm{CH}_{50}$ unit was calculated using the method of CAMPBELL ${ }^{8}$.

For determination of Hematocrit values, the blood aspirated into micro capillary stick was sealed with plastic clay and centrifuged at $15000 \mathrm{rpm}$ for $5 \mathrm{~min}$. The hematocrit values were read by using a Micro-Capillary Reader.

Data was evaluated by analysis of variance using least squares method of HARVEY ${ }^{9)}$.

\section{Results}

Total numbers of leukocytes for each line are given in Table 1. Total leukocyte numbers of both lines were similar at 3 and 9 weeks of age. Significant difference was observed only at 6 weeks of age $(\mathrm{P}<0.05)$. The differences seemed to be originated in lymphocyte numbers. The lymphocyte numbers were higher in the LA line than in the HA line at 6 and 9 weeks of age. Their differences were significant at $5 \%$ levels. However, no significant differences were seen for granulocyte and monocyte numbers during the experimental periods.

Table 2 shows hematocrit values of peripheral blood. Higher values were observed for the LA line as compared with the HA line. The differences were significant at 3 and 6 weeks of age. 
Table 1. The Comparison of Leukocyte Numbers between HA and LA lines of Chickens

\begin{tabular}{ccccccc}
\hline Age (wk) & line & $\mathrm{n}$ & total leukocytes & lymphocytes & monocytes & granulocytes \\
\cline { 5 - 7 } 3 & & & & $\left(/ \mathrm{mm}^{3}\right)$ & & \\
\cline { 5 - 6 } & H A & 16 & $23,325 \pm 1,490^{\mathrm{a}}{ }^{1)}$ & $21,777 \pm 1,383^{\mathrm{a}}$ & $631 \pm 85^{\mathrm{a}}$ & $918 \pm 104^{\mathrm{a}}$ \\
\multirow{2}{*}{6} & L A & 11 & $22,673 \pm 1,370^{\mathrm{a}}$ & $20,890 \pm 1,235^{\mathrm{a}}$ & $576 \pm 73^{\mathrm{a}}$ & $1,207 \pm 255^{\mathrm{a}}$ \\
& H A & 16 & $24,900 \pm 1,254^{\mathrm{a}}$ & $22,568 \pm 1,122^{\mathrm{a}}$ & $650 \pm 99^{\mathrm{a}}$ & $1,683 \pm 477^{\mathrm{a}}$ \\
\multirow{2}{*}{9} & L A & 11 & $30,109 \pm 2,104^{\mathrm{b}}$ & $27,372 \pm 2,074^{\mathrm{b}}$ & $804 \pm 92^{\mathrm{a}}$ & $1,932 \pm 250^{\mathrm{a}}$ \\
& H A & 16 & $26,425 \pm 1,457^{\mathrm{a}}$ & $23,399 \pm 1,223^{\mathrm{a}}$ & $943 \pm 120^{\mathrm{a}}$ & $2,083 \pm 393^{\mathrm{a}}$ \\
& L A & 11 & $30,236 \pm 1,923^{\mathrm{a}}$ & $27,428 \pm 1,460^{\mathrm{b}}$ & $915 \pm 183^{\mathrm{a}}$ & $1,893 \pm 545^{\mathrm{a}}$ \\
\hline
\end{tabular}

${ }^{1)}$ Means \pm S.E. For each age group, the means with different superscript within a column are significantly different $(\mathrm{P}<0.05)$.

$\mathrm{n}$ : Number of birds.

Table 2. Hematocrit Values of Peripheral Blood from HA and LA Lines of Chicken

\begin{tabular}{|c|c|c|c|c|}
\hline \multirow[b]{2}{*}{ line } & \multirow[b]{2}{*}{$\mathrm{n}$} & \multicolumn{3}{|c|}{ Age in weeks } \\
\hline & & 3 & 6 & 9 \\
\hline $\mathrm{HA}$ & 16 & $28.5 \pm 0.65^{\mathrm{a}^{1)}}$ & $\begin{array}{l}-(\%)- \\
27.5 \pm 0.62^{\mathrm{a}}\end{array}$ & $25.0 \pm 0.87^{a}$ \\
\hline $\mathrm{L} \mathrm{A}$ & 11 & $33.2 \pm 2.02^{\mathrm{b}}$ & $32.3 \pm 0.62^{b}$ & $27.8 \pm 1.10^{\mathrm{a}}$ \\
\hline
\end{tabular}

1) Means \pm S.E. Means with different superscript within a column are significantly different $(\mathrm{P}<0.05)$.

$\mathrm{n}$ : Number of birds.

Table 3. Plasma Hemolytic Complement Levels in HA and LA Lines of Chickens ${ }^{1)}$

\begin{tabular}{ccccc}
\hline & & \multicolumn{3}{c}{ Age in weeks } \\
\cline { 3 - 5 } line & $\mathrm{n}$ & $\begin{array}{c}3 \\
\text { means } \pm \text { S.E. }\end{array}$ & means \pm S.E. & means \pm S.E. \\
\hline H A & 16 & $48.9 \pm 3.39^{\mathrm{a}^{2)}}$ & $193.6 \pm 8.91^{\mathrm{a}}$ & $189.5 \pm 12.69^{\mathrm{a}}$ \\
L A & 11 & $38.7 \pm 3.89^{\mathrm{a}}$ & $138.3 \pm 14.2^{\mathrm{b}}$ & $128.3 \pm 9.88^{\mathrm{b}}$ \\
\hline
\end{tabular}

1) Complement level was expressed by $\mathrm{CH}_{50}$ unit per milliter.

2) Means \pm S.E. Means with different superscript within a column are significantly different $(\mathrm{P}<0.05)$.

$\mathrm{n}$ : Number of birds.

On the other hand, hemolytic complement levels of the HA line was higher than that of LA line as shown in Table 3. Significant differences were seen at 6 and 9 weeks of age.

\section{Discussion}

The present study has demonstrated the differences in peripheral leukocyte numbers between HA and LA lines. Especially, lymphocyte number of LA line was higher than that of HA line. AshikAGa et $a l^{3)}$ and OKADA and YAmamoto ${ }^{4)}$ found that LA line 
was more resistant to Marek's disease than HA line, and suggested that the resistance might be brought about by a low level of lymphoproliferative response of LA line. It has been demonstrated that LA line shows lower competences in GVHR and immune response than HA line ${ }^{1,2,5)}$. Contrary to this, the present study has shown that LA line has more lymphocytes than HA line. So, it is considered that the differences in the competences between the two lines might not be related to the numbers of lymphocyte. Perhaps, HA line might show higher competence in lymphoproliferative ability as compared with LA line when antigenic stimulation is given. This problem remains to be investigated.

Previously, CHANH and his associates ${ }^{7)}$ suggested that hemolytic complement level is controlled by MHC. In the present study, it was shown that hemolytic complement levels differed between the two lines which had the same B genotype. The result suggests the presence of another gene(s) which might cooperate with MHC to determine the hemolytic complement level. It has been reported that the complement Factor-B is not associated with MHC in chickens ${ }^{10)}$, while the character is controlled by $\mathrm{MHC}$ in mammals ${ }^{11}$. The above finding also suggests that the complement system of chickens may differ from that of mammals.

\section{Acknowledgment}

The technical assistance of Mr. T. TAKeshi and Ms. T. OHyama is gratefully appreciated.

\section{References}

1) Okada, I and H. Mikami (1974) Three generation of selection for high and low donor competences of splenomegaly in chicken. Br. Poult. Sci., 15 : 1-10.

2) Yanagimoto, Y. and I. Oкаda (1980) Evidence for major histocompatibility linked and non-linked genetic regulation of immune response in chickens. Jpn. Zootech. Sci., $51:$ 127-134.

3) Ashikaga, M., I. Okada, Y. Yamamoto and H. Matuda (1984) Interaction of GVHR selected line and the B genotypes in the genetic resistance to Marek's disease. Jpn. Poult. Sci., 21 : 102-110.

4) OKAdA, I. and Y. Yамамото (1987) Immunocompetences and Marek's disease resistance in three pairs of chicken lines selected for different immunological characters. Poult. Sci., 66 : 769-773.

5) Okada, I., Y. Yamamoto and M. Mizuyama (1987) Parabiosis between avian embryos selected for high and low competences of the graft-versus-host reaction. Poult. Sci., 66 : 1090-1094.

6) Shen, P.H., E.J. Smith, L.D. BAcon (1984) The ontogeny of blood cells, complement and immunoglobulins in 3 - to 12 - week-old $1515-\mathrm{B}$ congenic White Leghorn chickens. Poult. Sci., 63 : 1083-1093.

7) Chanh, T.C., A.A. Benedict and H. Abplanalp (1976) Association of serum hemolytic complement levels with the major histocompatibility complex in chickens. J. Exp. Med., 144 : 555-561.

8) Campbell, D.H., J.S. Garvey, N.E. Cremer and D.H. Sussdorf (1970) Method in Immunology, A Laboratory text for instruction and research., 2nd ed. W.A. Benjamin. inc., Readin, MA. 300-313.

9) HaRveY, W.R. (1960) Least-square analysis of DATA with unequal subclass number. Agriculture Research Service, USDA. 2-17. 
10) Koch, C. (1986) A genetic polymorphism of complement Factor B in chickens not linked to major histocompatibility complex (MHC). Immunogenetics, 23 : 364-367.

11) Roum, D., D. Grass, C.B. Carpenter, C.A. Alper and P.H. Shur (1976) The chromosomal order of genes controlling the major histocompatibility complex, prepadin Factor B, and deficiency of the second component of complement. J. Clin. Invest., $58:$ 1240-1246.

\title{
移植片対宿主反応によって二方向選抜された \\ 系統 HA および LA 鶏における白血球数, ヘマトクリット值ならびに補体価の比較
}

\author{
真島 傑 - 奥村仁一 ${ }^{1} \cdot$ 岡田育穂 $^{2} \cdot$ 山本興三郎 ${ }^{1}$ \\ 新潟大学自然科学研究科, 新潟市 950-21 \\ ${ }^{1}$ 新潟大学農学部, 新潟市 $950-21$ \\ ${ }^{2}$ 公島大学生物生産学部，東公島市 720
}

\section{移植片対伯主反応に打ける脾腫能力の違いによって選} 抜された，HA 系統と LA 系統の間で，3，6ならびに 9 週龄における木梢血液中の総白向球数, 各白和球数, 補体価ならびにへマトクリット值を比較した。

総白向球数は, 3 週齢および 9 週齢では系統問で有意 な差違は認められなかった。しかし，6週秢では，LA 系統が HA 系統に比べ有意に高い值を示した $(\mathrm{P}<0.05)$ 。 総白向球の差はリンパ球数の差違に依仔しており, 6 週 粈ならびに 9 週齢で LA 系統のリンパ球数はHA 系統 の数を上问った。一可, 単球および顆粒球の数は両系統 閌に差違は認められなかった。へマトクリット值は，3，
6 週跘で LA 系統の值が HA 系統の值を上囘ったが, 9 週龄では両系統間に有意な差は認められなかった。マ レック病抵抗性および白向球数の差違に基づいて抗原刺 激が加えられた場合の両系統のリンパ球増殖能力に関し 考察が行われた。補体価は，3週齢で両系統問に差造は 兄られなかったものの，6，9週齢では HA 系統の值が LA 系統に比べ, 有意に高い值を示し $(\mathrm{P}<0.05), こ$ れらの系統が鶏の補体系の研究に有用であることを示唆 した。

（家离会誌, $28 ： 256 \sim 260,1991$ ) キーワード : 補体価, 白向球数, ヘマトクリット值 